American Journal of Environmental Sciences 6 (6): 535-547, 2010

ISSN 1553-345X

(C) 2010 Science Publications

\title{
Analysis of Evapotranspiration Variability and Trends in the Arabian Peninsula
}

\author{
${ }^{1}$ Mohammad ElNesr, ${ }^{1}$ Abdulrahman Alazba and ${ }^{2}$ Majed Abu-Zreig, \\ ${ }^{1}$ Alamoudi Water Chair, King Saud University, Riyadh, Kingdom of Saudi Arabia \\ ${ }^{2}$ Department of Civil Engineering, Jordan University of Sci. and Tech., Irbid, Jordan
}

\begin{abstract}
Problem statement: Climate variability is receiving much attention recently because it has significant effects on water resources and therefore on the livelihood of society especially in water scarce countries such the Kingdom of Saudi Arabia (KSA). Approach: The aim of this study was to explore changes in the reference evapotranspiration $\left(\mathrm{ET}_{\mathrm{o}}\right)$ using data from 27 weather stations through years 1980-2008 and to identify trend directions in the $\mathrm{ET}_{\mathrm{o}}$ as an indicator to climate variability in the region. $\mathrm{ET}_{\mathrm{o}}$ was calculated using FAO-56 Penman Monteith method and trends analyses were performed with non-parametric statistics proposed by Mann-Kendall and Sen slope estimator. Results: Results indicated that the average $\mathrm{ET}_{\mathrm{o}}$ varied from $5 \mathrm{~mm}_{\text {day }}{ }^{-1}$ in January to more than $15 \mathrm{~mm}_{\text {day }}{ }^{-1}$ in July with extreme average values ranged from $4 \mathrm{~mm} \mathrm{day}^{-1}$ in January to $18 \mathrm{~mm} \mathrm{day}^{-1}$ in July. The trend analyses indicated that the average annual maximum and minimum daily $\mathrm{ET}_{\mathrm{o}}$ steadily increased over the study period. The $\mathrm{ET}_{\mathrm{o}}$ annual daily average had increased from about $9.6 \mathrm{~mm} \mathrm{day}^{-1}$ in 1980 to $10.5 \mathrm{~mm}^{-1}{ }^{-1}$ in 2008 . Trend analysis with Mann-Kendall and Sen Slope gave consistent results and were able to detect trend direction and its significant level for each month and for each station. In general, most of stations showed an increasing trend especially in the Northern parts of KSA and along the longitudinal line of $45^{\circ}$. 'Yenbo' station showed a significant increasing trend in $\mathrm{ET}_{\mathrm{o}}$ for the entire year. The increasing trends prevailed during most of the year except in the winter months from October to January. Even during these winter months, significant decreasing trends were observed for only four stations. Conclusion: It is recommended to perform similar studies on other parts of the Arabian Peninsula using wider databases, and to consider the increasing trend of $\mathrm{ET}_{\mathrm{o}}$ in the planning for agricultural and water resources projects.
\end{abstract}

Key words: Climate variability, evapotranspiration variability, trend analysis, arid lands, agricultural production, Saudi Arabia.

\section{INTRODUCTION}

Recently, considerable interest has been shown to climate variability and its effect on the hydrological cycle and water supply (Schwartz and Randall, 2003). Research was conducted to detect climate changes, trends and variability in various parts of the world utilizing some climate parameters such as air temperature, rainfall depth, reference evapotranspiration $\mathrm{ET}_{\mathrm{o}}$ and pan evapotranspiration $\mathrm{ET}_{\mathrm{p}}$ (Schwartz and Randall, 2003; Garbrecht et al., 2004; Hegerl et al., 2007; Fu et al., 2009; Saghravani et al., 2009; Hakan et al., 2010). $\mathrm{ET}_{\mathrm{o}}$ is of particular importance because it combine changes in many other climate parameters including temperature, radiation, humidity and wind speed. It has, however, direct influence on hydrologic water balance, irrigation and drainage canal design, reservoir operation, potentials for rain-fed agricultural production and crop water requirements (Dinpashoh, 2006).
Several studies conducted in North America have shown that some climate parameters are on the rise including $\mathrm{ET}_{\mathrm{o}}$ (Fehrman, 2007; Garbrecht et al., 2004; Szilagyi, 2001). Fehrman (2007) found an increasing trend in $\mathrm{ET}_{0}$ over the Mississippi area and that most of $\mathrm{ET}_{\mathrm{o}}$ increase can be attributed to the increase in July. $\mathrm{He}$ also found that the rate of $\mathrm{ET}_{\mathrm{o}}$ increase was 0.29 $\mathrm{mm}$ years ${ }^{-1}$ when his study period extended from 19401999 compared to $0.88 \mathrm{~mm}$ year $^{-1}$ when the study period was limited to $1950-1999$ records. The accelerated ET over North America is presumed to be due to a rise in temperature over the past century (Myneni et al., 1997, Milly and Dunne, 2001). In the contrary $\mathrm{ET}_{\mathrm{o}}$ and pan evaporation has shown to decrease in China (Thomas, 2000; Liu et al., 2004) and at a rate of $1.19 \mathrm{~mm} \mathrm{year}^{-1}$ (Song et al., 2010) despite the rise in maximum daily temperature. In the Tibetan Plateau $\mathrm{ET}_{0}$ decreases as well at a rate of $1.31 \mathrm{~mm}$ year $^{-1}$ or $2.0 \%$ of the annual total evapotranspiration (Shenbin et al., 2006). The decrease in $\mathrm{ET}_{\mathrm{o}}$ has been

Corresponding Author: Mohammad N. ElNesr, Alamoudi Water Chair, King Saud University, P.O. Box 2460, Riyadh 11451, Tel: 966544909445 
attributed to the decrease in wind speed and net radiation. In another study Gao et al. (2007) found that the actual evapotranspiration had a decreasing trend in most of the eastern part of china and there was an increasing trend in the western and the northern parts of northeast China and that the change in precipitation played a key role for the change of estimated actual evapotranspiration. Similar negative trends in pan evaporation were found in 24 out of 27 observation stations in a 19-year study in Thailand (Tebakari et al., 2005). In India, a significant decreasing trend was found in $\mathrm{ET}_{\mathrm{o}}$ all over the Indian plateau during the past 40 years, which was mainly caused by a significant increase in the relative humidity and a consistent significant decrease in the wind speed throughout the country (Bandyopadhyay et al., 2009). In Australia, Roderick and Farquhar (2004) found a decreasing trend in pan evaporation and conclude that Australia is becoming less arid. However, there is enough evidence now that a decrease in pan evaporation is an indicator to an increase in actual evaporation. This is what known now as the evaporation paradox (Hobbins et al., 2004).

However, changes in climate parameters in Middle Eastern climate have received little attention in global and local level, even though these countries suffer severe environmental, agricultural and water resources problems. Temperature is expected to raise in this area thus increasing evapotranspiration. Furthermore, most of literature studies conducted in that area have focused on studying time changes in temperature and or rainfall. Hakan et al. (2010) reported an increasing trend in temperature and $\mathrm{ET}_{\mathrm{o}}$ in most of stations they analyzed in Turkey using Mann-Kendall analysis. Cohen and Stanhill (1996) studied rainfall changes in the Jordan Valley/Jordan and found a tangible but insignificant decrease at a rate of -0.47 and $-0.16 \mathrm{~mm} \mathrm{year}^{-1}$ for two different stations. Similar conclusions were observed by Al-Ansari et al. (1999) who observed a general decrease in rainfall intensity. Smadi (2006) and Smadi and Zghoul (2006) found a prompt shift in rainfall and temperature in Jordan. ElNesr et al. (2010) concluded that the Saudi Arabia and the Arabian Peninsula are suffering from a considerable warming trend form year 1980-2008. However, no comprehensive studies have been found to examine $\mathrm{ET}_{\mathrm{o}}$ trends in the more arid countries in the Middle East like Saudi Arabia. Therefore, identifying changes in $\mathrm{ET}_{\mathrm{o}}$ is necessary for future planning of agriculture-water projects for those countries like Saudi Arabia.

The Kingdom of Saudi Arabia (KSA) is one of the most arid countries in the world and suffers chronic water resources and water shortage problems. The Kingdom suffers large water supply deficit since more than $88 \%$ of water consumption is due to agricultural related activities (Abderrahman, 2001). Agricultural water requirements are determined initially by identifying the reference evapotranspiration $\left(\mathrm{ET}_{\mathrm{o}}\right)$. The main solution of the water problem is an efficient water management and better prediction for demand and supply. Rain in KSA is the only renewable water source and comes in flash short duration storms of high intensity and most of it vanishes to evaporation.

Global warming or green house effect has been shown to affect the earth climate (Hegerl et al., 2007). Some researchers developed a hypothetical scenario to study the effect of possible increase on temperature over the KSA on $\mathrm{ET}_{\mathrm{o}}$ and subsequently on water supply. A study conducted by Abderrahman et al. (1991) concluded that a $1{ }^{\circ} \mathrm{C}$ increase in temperature would increase $\mathrm{ET}_{0}$ from 1-4.5\%. In another study, that includes selected cities in Saudi Arabia, United Arab Emirates and Kuwait, Abderrahman and Al-Harazin (2003) concluded that an increase in temperature by $1{ }^{\circ} \mathrm{C}$ would increase $\mathrm{ET}_{\mathrm{o}}$ over these area by a maximum of $20 \%$. However, no studies have been conducted to quantify time changes of temperature or $\mathrm{ET}_{\mathrm{o}}$ in the Arabian peninsula. Moreover, studies involving $\mathrm{ET}_{\mathrm{o}}$ calculation seemed to be more limited worldwide compared to other climate parameters. Consequently, the aim of this study is to quantify $\mathrm{ET}_{\mathrm{o}}$ and its time and space changes in Saudi Arabia during years 1980-2008 (29 years). We used the historical climate data for 27 stations to calculate $\mathrm{ET}_{\mathrm{o}}$ in each station, using Penman Monteith equation. The analyses of monthly $\mathrm{ET}_{\mathrm{o}}$ changes was carried out using Mann-Kendall and Sen slope tests. These tests are used to demonstrate any presence of possible trends against the null hypothesis of having no trends.

\section{MATERIALS AND METHODS}

Study area: Saudi Arabia is the largest country of the Arabian Peninsula; it occupies about $80 \%$ of its area (Wynbrandt, 2004). The country lies between latitudes $16^{\circ} 21^{\prime} 58^{\prime \prime} \mathrm{N}$ and $32^{\circ} 9^{\prime} 57^{\prime \prime} \mathrm{N}$ and longitudes $34^{\circ} 33^{\prime} 48^{\prime \prime} \mathrm{E}$ and $55^{\circ} 41^{\prime} 29^{\prime \prime} \mathrm{E}$, as illustrated in Fig. 1. Saudi Arabia has a desert dry climate with high temperatures in most of the country. However, the country falls in the tropical and subtropical desert region. Winds reaching the country are generally dry and almost all the area is arid. Because of the aridity and the relatively cloudless skies, there are great extremes in temperature, but there are also wide variations between the seasons and regions (Aquastat, 2008). The average annual daily mean temperature varied from about $15^{\circ} \mathrm{C}$ in January to as high as $33^{\circ} \mathrm{C}$ in July. Rainfall depths varied from 300 $\mathrm{mm}$ year $^{-1}$ in the southwestern areas to zero in the eastern desert (Abdullah and Al-Mazroui, 1998). 
Am. J. Environ. Sci., 6 (6): 535-547, 2010

Table 1: Geographical information of the meteorological stations included in this study

\begin{tabular}{|c|c|c|c|c|c|c|}
\hline \multirow[b]{3}{*}{ District } & \multirow{2}{*}{\multicolumn{2}{|c|}{ Station }} & \multicolumn{3}{|c|}{ Station coordinates } & \multirow{3}{*}{$\begin{array}{l}\text { Recroded } \\
\text { Years** }\end{array}$} \\
\hline & & & \multirow{2}{*}{$\begin{array}{l}\text { Latitude } \\
\text { Deg. N. }\end{array}$} & \multirow{2}{*}{$\begin{array}{l}\text { Longitude } \\
\text { Deg. East }\end{array}$} & \multirow[b]{2}{*}{ Altitude $\mathrm{m}$} & \\
\hline & ID & Name & & & & \\
\hline Northern & 1 & Turaif & 31.41 & 38.4 & 818 & 29 \\
\hline \multirow[t]{2}{*}{ Borders } & 2 & Arar & 31.00 & 41.00 & 600 & 29 \\
\hline & 5 & Rafha & 29.38 & 43.29 & 447 & 29 \\
\hline \multirow[t]{2}{*}{ AlJouf } & 3 & Guraiat* & 31.50 & 37.50 & 560 & 4 \\
\hline & 4 & Al Jouf & 29.47 & 40.06 & 671 & 29 \\
\hline \multirow{2}{*}{ Tabuk } & 7 & Tabuk & 28.22 & 36.38 & 776 & 29 \\
\hline & 10 & Wejh & 26.12 & 36.28 & 21 & 29 \\
\hline Ha'il & 9 & Hail & 27.26 & 41.41 & 1013 & 29 \\
\hline AlQaseem & 11 & Gassim & 26.18 & 43.46 & 650 & 29 \\
\hline Eastern & 6 & Qaisumah & 28.32 & 46.13 & 358 & 29 \\
\hline \multirow[t]{4}{*}{ Region } & 8 & Hafr Al-Batin & 28.20 & 46.07 & 360 & 19 \\
\hline & 12 & Dhahran & 26.16 & 50.10 & 17 & 29 \\
\hline & 13 & Dammam* & 26.42 & 50.12 & 1 & 9 \\
\hline & 14 & Ahsa & 25.30 & 49.48 & 179 & 24 \\
\hline \multirow[t]{3}{*}{ Riyadh } & 16 & Riyadh North & 24.42 & 46.44 & 611 & 24 \\
\hline & 17 & Riyadh Middle & 24.63 & 46.77 & 624 & 29 \\
\hline & 23 & W-Dawasir & 20.50 & 45.16 & 652 & 24 \\
\hline \multirow[t]{2}{*}{ Madina } & 15 & Madina & 24.33 & 39.42 & 636 & 29 \\
\hline & 18 & Yenbo & 24.09 & 38.04 & 6 & 29 \\
\hline \multirow[t]{3}{*}{ Makkah } & 19 & Jeddah & 21.30 & 39.12 & 17 & 29 \\
\hline & 20 & Makkah & 21.40 & 39.85 & 213 & 24 \\
\hline & 21 & Taif & 21.29 & 40.33 & 1454 & 29 \\
\hline Baha & 22 & Baha & 20.30 & 41.63 & 1652 & 24 \\
\hline \multirow{3}{*}{ Aseer } & 24 & Bisha & 19.59 & 42.37 & 1163 & 29 \\
\hline & 25 & Abha & 18.14 & 42.39 & 2093 & 29 \\
\hline & 26 & Khamis Mushait & 18.18 & 42.48 & 2057 & 29 \\
\hline \multirow[t]{2}{*}{ Nagran } & 27 & Nejran & 17.37 & 44.26 & 1210 & 29 \\
\hline & 28 & Sharurrah & 17.47 & 47.11 & 725 & 24 \\
\hline Gizan & 29 & Gizan & 16.54 & 42.35 & 3 & 29 \\
\hline
\end{tabular}

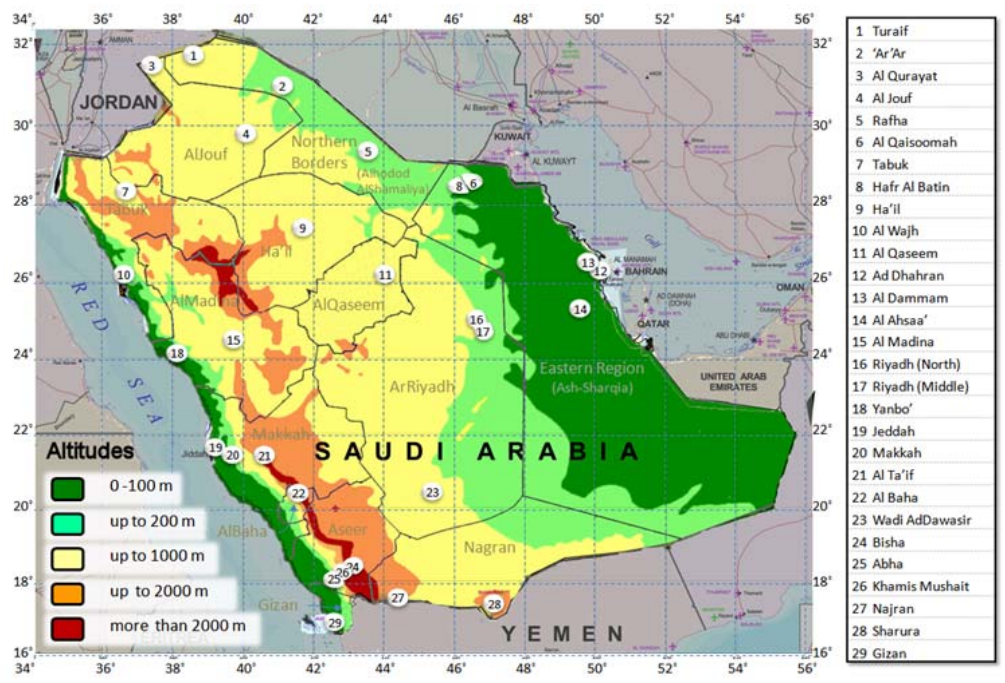

Fig. 1: Geographic map of Saudi Arabia, showing 13 districts and 29 meteorological stations. Base map Src: NIMA (2003). Districts Src: Momra (2007), Topography

Climate data: Climatic data was taken from the Presidency of Meteorology and Environment in KSA. Data represents 29 meteorological stations as shown in Fig. 1. These stations represent all the 13 districts of the
KSA. The data covers 29 years of daily meteorological information in most stations. Detailed information about each station is listed in Table 1. For each station, data were recorded in daily intervals, the recorded data were: 
- Dry bulb temperature (maximum, average and minimum) $\left[{ }^{\circ} \mathrm{C}\right]$

- Wet bulb temperature (maximum, average and minimum) $\left[{ }^{\circ} \mathrm{C}\right]$

- Relative humidity (maximum, average and minimum) [\%]

- Atmospheric pressure at station level (maximum, average and minimum) $[\mathrm{kPa}]$

- Wind speed (maximum and average) $\left[\mathrm{m} \mathrm{sec}^{-1}\right]$

- Other properties, which were not used in this study like the prevailing wind direction, rainfall, sky coverage

The obtained climatic data records were carefully inspected for missing and erroneous reading. Errors were classified into four categories: Errors because of mistaken extreme values; such as a relative humidity exceeds $100 \%$ or below $0 \%$; Illogical errors such as the recorded maximum daily temperature $\left(\mathrm{T}_{\mathrm{x}}\right)$ was less than the minimum daily temperature $\left(T_{n}\right)$ in the same day, or if $T_{x}=T_{n}$; Missing values; i.e., $T_{x}$ is present but $T_{n}$ is missing; and Some stations record a known number like 999 or 777 if the sensor is damaged or faulty. However, the missing and erroneous data in all stations are less than $0.7 \%$ in the study period.

FAO-56 method: $\mathrm{ET}_{\mathrm{o}}$ was estimated using the FAO56 Penman-Monteith equation for daily EToin $\mathrm{mm} \mathrm{d}-1$ after Allen et al. (1998):

$$
\mathrm{ET}_{\mathrm{o}}=\frac{0.408 \Delta\left(\mathrm{R}_{\mathrm{n}}-\mathrm{G}\right)+\frac{900}{\left(\mathrm{~T}_{\mathrm{a}}+273\right)} \gamma \mathrm{U}_{2}\left(\mathrm{e}_{\mathrm{s}}-\mathrm{e}_{\mathrm{a}}\right)}{\Delta+\gamma\left(1+0.34 \mathrm{U}_{2}\right)}
$$

Where:

$\mathrm{R}_{\mathrm{n}}=$ The net radiation at the crop surface $\left[\mathrm{MJ} \mathrm{m}^{-2}\right.$ day $^{-1}$ ]

$\mathrm{G}=$ The soil heat flux density $\left[\mathrm{MJ} \mathrm{m}^{-2}\right.$ day $\left.^{-1}\right]$

$\mathrm{T}_{\mathrm{a}}=$ The mean daily air temperature at $2 \mathrm{~m}$ height $\left[{ }^{\circ} \mathrm{C}\right]$

$\mathrm{U}_{2}=$ The wind speed at $2 \mathrm{~m}$ height $\left[\mathrm{m} \mathrm{sec}^{-1}\right]$,

$\mathrm{e}_{\mathrm{s}}=$ Saturation vapor pressure $[\mathrm{kPa}]$

$\mathrm{e}_{\mathrm{a}}=$ Actual vapor pressure [kPa]

$\Delta=$ The slope of vapour pressure curve $\left[\mathrm{kPa}^{\circ} \mathrm{C}^{-1}\right]$

$\gamma=$ The psychrometric constant $\left[\mathrm{kPa}{ }^{\circ} \mathrm{C}^{-1}\right]$

The measured meteorological data available were $\mathrm{T}_{\mathrm{a}}$, Relative Humidity (RH) and $\mathrm{U}_{2}$ whereas soil heat flux (G) was taken equal to zero, $\mathrm{G}=0$ (Allen et al., 2005). The slope of the saturation vapour pressure curve $(\Delta)$ is computed by the following equation as in Murray (1967):

$$
\Delta=\frac{4098 \times \mathrm{e}_{\mathrm{o}}\left[\mathrm{T}_{\mathrm{a}}\right]}{\left(\mathrm{T}_{\mathrm{a}}+237.3\right)^{2}}
$$

where, $e_{0}\left[T_{a}\right]$ is calculated according to (Tetens, 1930):

$$
e_{o}[T]=0.611 \exp \left(\frac{17.27 T}{T+237.3}\right)
$$

The net radiation $R_{n}$ was estimated as the difference between the net short wave incoming radiation $R_{n s}$ and the net long wave outgoing radiation $\mathrm{R}_{\mathrm{n}}$. The calculation of $\mathrm{R}_{\mathrm{ns}}$ and $\mathrm{R}_{\mathrm{nl}}$, followed the procedures outlined in Allen et al. (1998) and Doorenbos and Pruitt (1975). All radiation was computed in daily energy flux units $\left(\mathrm{MJ} \mathrm{m}^{-2}\right.$ day $\left.^{-1}\right)$. Allen et al. (1998) reported a validated formula to calculate the incoming solar radiation $R_{s}$ from air temperature difference:

$$
\mathrm{R}_{\mathrm{s}}=\mathrm{c} \mathrm{R}_{\mathrm{a}} \sqrt{\mathrm{T}_{\mathrm{x}}-\mathrm{T}_{\mathrm{n}}}
$$

Where:

$\mathrm{R}_{\mathrm{a}}=$ Extraterrestrial radiation $\left[\mathrm{MJ} \mathrm{m}^{-2} \mathrm{~d}^{-1}\right]$,

$\mathrm{c}=$ An adjustment coefficient $=0.19$ for coastal stations and 0.16 for inland stations

$\mathrm{T}_{\mathrm{n}}=$ Minimum dry bulb air temperature $\left[{ }^{\circ} \mathrm{C}\right]$

$\mathrm{T}_{\mathrm{x}}=$ Maximum dry bulb air temperature $\left[{ }^{\circ} \mathrm{C}\right]$.

The psychometric constant $\gamma$ is evaluated as:

$$
\gamma=0.00163 \frac{P}{\lambda}
$$

Where:

$\begin{aligned} \mathrm{P} & =\text { Atmospheric pressure }[\mathrm{kPa}] \\ \lambda & =\text { Latent heat flux }\left[\mathrm{MJ} \mathrm{kg}^{-1}\right]\end{aligned}$

The atmospheric pressure is expressed as in Burman et al. (1987)

$$
\mathrm{P}=101.3\left(\frac{293-0.0065 \mathrm{z}}{293}\right)^{5.26}
$$

where, $z$ : altitude $[\mathrm{m}]$. The latent heat $\lambda$ depends on the average temperature, Eq. 7, while it can be taken as an approximate value of 2.45 for $\mathrm{T}_{\mathrm{a}}=20^{\circ} \mathrm{C}$. In the current study, we chose to calculate the latent heat using Eq. 7.

$\lambda=2.5-0.00236 \mathrm{~T}_{\mathrm{a}}$

The saturation vapor pressure, $e_{s}$ and actual vapour pressure, $\mathrm{e}_{\mathrm{a}}$, are calculated according to Allen et al. (2005) as: 
$\mathrm{e}_{\mathrm{s}}=0.5\left(\mathrm{e}_{\mathrm{o}}\left[\mathrm{T}_{\mathrm{n}}\right]+\mathrm{e}_{\mathrm{o}}\left[\mathrm{T}_{\mathrm{x}}\right]\right)$

$\mathrm{e}_{\mathrm{a}}=0.005\left(\mathrm{RH}_{\mathrm{x}} \mathrm{e}_{\mathrm{o}}\left[\mathrm{T}_{\mathrm{n}}\right]+\mathrm{RH}_{\mathrm{n}} \mathrm{e}_{\mathrm{o}}\left[\mathrm{T}_{\mathrm{x}}\right]\right)$

Where:

$\mathrm{RH}_{\mathrm{x}}=$ Maximum relative humidity [\%]

$\mathrm{RH}_{\mathrm{n}}=$ Minimum relative humidity [\%]

The average daily $\mathrm{ET}_{\mathrm{o}}$ in a specific month was calculated by taking the arithmetic average of the daily values in that month. The summation of all $\mathrm{ET}_{\mathrm{o}}$ daily values in a year for a station will give the total annual $\mathrm{ET}_{\mathrm{o}}$ for that station.

Mann-Kendall test: The Mann-Kendall test is a nonparametric test used for identifying trends in time series data. The test compares the relative magnitudes of sample data rather than the data values themselves Both Kendall tau coefficient $(\tau)$ and Mann-Kendall coefficient (s) are nonparametric statistics used to find rank correlation. Kendall $(\tau)$ is a ratio between the actual rating score of correlation, to the maximum possible score. To obtain the rating score for a time series, the dataset is sorted in ascending order according to time and then the following formula is applied:

$\mathrm{S}=\sum_{\mathrm{j}=1}^{\mathrm{j}=\mathrm{n}-1} \sum_{\mathrm{i}=\mathrm{j}+1}^{\mathrm{i}=\mathrm{n}} \operatorname{Sign}\left(\mathrm{x}_{\mathrm{i}}-\mathrm{x}_{\mathrm{j}}\right)$

Where:

$\mathrm{s} \quad=$ The rating score (also called the MannKendall sum)

$\mathrm{x}=$ The data value

$\mathrm{i}$ and $\mathrm{j}=$ Counters

$\mathrm{n} \quad=$ Number of data values in the series

Sign $=$ A function having values of $+1,0,-1$ if $\left(\mathrm{x}_{\mathrm{i}}-\mathrm{x}_{\mathrm{j}}\right)$ is positive, zero, or negative, respectively

According this formula, the maximum value of $\mathrm{s}$ is:

$\mathrm{s}_{\max }=\frac{1}{2} \mathrm{n}(\mathrm{n}-1)$

Hence, the Kendall $(\tau)$ is calculated as: $\tau=\frac{\mathrm{s}}{\mathrm{S}_{\max }}$

A positive value of $\mathrm{s}$ or $\tau$ is an indicator of an increasing trend, and a negative value indicates a decreasing trend. However, it is necessary to compute the probability associated with $\mathrm{s}$ or $\tau$ and the sample size, $\mathrm{n}$, to quantify the significance of the trend statistically. Kendall and Gibbons (1990) introduced a normal-approximation test that could be applied on datasets of more than ten values with s variance $\left(\sigma^{2}\right)$ :

$\sigma^{2}=\frac{1}{18} n(n-1)(2 n+5)-C F_{R}$

$\mathrm{CF}_{\mathrm{R}}=\frac{1}{18} \sum_{\mathrm{k}=1}^{\mathrm{g}} \mathrm{m}_{\mathrm{k}}\left(\mathrm{m}_{\mathrm{k}}-1\right)\left(2 \mathrm{~m}_{\mathrm{k}}+5\right)$

where, $\mathrm{CF}_{\mathrm{R}}$ : repetition correction factor, to fix the effect of tied groups of data (when some of the data values appear more than one time in the dataset, this group of values are called a tied group); g: number of tied groups; $\mathrm{k}$ : a counter; $\mathrm{m}$ : number of data values in each tied group. Then normal distribution parameter (called the Mann-Kendall statistic, Z) is calculated as follows:

$Z=\left\{\begin{array}{ccc}\frac{1}{\sigma}(s-1) & \cdots & s>0 \\ 0 & \cdots & s=0 \\ \frac{1}{\sigma}(s+1) & \cdots & s<0\end{array}\right.$

The last step is to find the minimum probability level at which the parameter $\mathrm{Z}$ is significant, this could be found using two-tailed $\mathrm{t}$ statistical tables or as mentioned by Abramowitz and Stegun (1972):

$$
\alpha_{\min }=\left(\mathrm{b}_{0} \mathrm{e}^{-0.5 \mathrm{Z}^{2}}\right) \sum_{\mathrm{q}=1}^{\mathrm{q}=5} \mathrm{~b}_{\mathrm{q}} \cdot\left(1+\mathrm{b}_{6} \operatorname{ABS}(\mathrm{z})\right)^{-\mathrm{q}}
$$

Where:

$\alpha_{\min }=$ Minimum level of significance

$\mathrm{q}=$ counter

$\mathrm{b}_{\mathrm{x}} \quad=$ constants: $\mathrm{b}_{0}=0.3989, \mathrm{~b}_{1}=$ $0.3194, b_{2}=-0.3566, b_{3}=1.7814, b_{4}=-$ $1.8213, b_{5}=1.3303, b_{6}=0.2316$

$\operatorname{ABS}(Z)=A$ function returns the absolute value of $Z$.

Kendall tau is considered significant when alpha $\min$ is less than a specified alpha value, i.e., 0.05.

Sen Slope estimator test: Sen's statistic is the median slope of each point-pair slope in a dataset (Sen, 1968). To perform the complete Sen's test, several rules and conditions should be satisfied; the time series should be equally spaced, i.e. the interval between data points 
should be equal. However, Sen's method considers missing data. The data should be sorted ascending according to time, and then apply the following formula to calculate Sen's slope estimator (Q) as the median of Sen's matrix members:

$Q=\operatorname{Median}\left\{\left[\left[\frac{x_{i}-x_{j}}{i-j}\right]_{j=1}^{j=n-1}\right]_{i=j+1}^{i=n}\right\}$

Its sign reflect the trend's direction, while its value reflects how steep the trend is. To determine whether the median slope is statistically different than zero, the variance is calculated using Eq. 13, to obtain the confidence interval of $\mathrm{Q}$ at a specific probability level, e.g., 95\%. The area $(Z)$ under two-tailed normal distribution curve is calculated at the level $(1-\alpha / 2)$, where $\alpha=1$-confidence level. For example, for a confidence level of $95 \%, \mathrm{Z}$ should be evaluated at 0.975 , hence $Z=1.96$. After that, the parameter $C_{\alpha}$ is calculated as follows:

$$
\mathrm{C}_{\alpha}=\mathrm{Z}_{1-\alpha / 2} \sqrt{\sigma^{2}}
$$

The upper and lower confidence boundaries for Q are then calculated as follows:

$$
\begin{aligned}
& \mathrm{M}_{\mathrm{u}}=\operatorname{int}\left(0.5\left(\mathrm{n}_{\mathrm{q}}-\mathrm{C}_{\alpha}\right)\right) \\
& \mathrm{M}_{1}=\operatorname{int}\left(0.5\left(\mathrm{n}_{\mathrm{q}}+\mathrm{C}_{\alpha}\right)\right)+1
\end{aligned}
$$

where, int() represents the integer value; $\mathrm{M}_{\mathrm{u}}$ and $\mathrm{M}_{1}$ are the upper and lower boundaries for $\mathrm{Q}$ at $1-\alpha$ probability level; $\mathrm{n}_{\mathrm{q}}$ is the number of Sen's matrix members calculated from Eq. 17 equal to $n_{q}=n(n-1)$. The median slope is then defined as statistically different from zero for the selected confidence interval if the zero does not lie between the upper and lower confidence limits.

\section{RESULTS AND DISCUSSION}

The daily $\mathrm{ET}_{\mathrm{o}}$ data for each of the studied stations were calculated for the study period. Then we summarize the data on monthly basis to find the average, maximum and minimum values per month for the whole country, Fig. 2. The lowest values of $\mathrm{ET}_{\mathrm{o}}$ occurred in the winter season, December and January whereas the highest values occurred during summer months; June, July and August. The results showed high variation in $\mathrm{ET}_{\mathrm{o}}$ from about $5-15 \mathrm{~mm}$ day $^{-1}$ in July whereas the absolute minimum and maximum $\mathrm{ET}_{\mathrm{o}}$ showed even higher variation and ranged from $3.9 \mathrm{~mm} \mathrm{day}^{-1}$ in January to as high as $18.5 \mathrm{~mm} \mathrm{day}^{-1}$ in July. However, Fig. 2 indicates the high variability of climate conditions over Saudi Arabia, which highlights the major challenge for agricultural development and water resources planning in the country.

The variation of $\mathrm{ET}_{\mathrm{o}}$ over the Arabian Peninsula is large, as it should be due to its large surface area and large differences in altitudes. Therefore, the average $\mathrm{ET}_{0}$ values in the study period for the studied stations were plotted with their altitude, latitude and longitudes and the results are shown in Fig. 3-5, respectively.

As expected $\mathrm{ET}_{\mathrm{o}}$ decreased with station altitude as weather stations varied from sea level, Yenbo' and Jeddah stations to as high as $2300 \mathrm{~m}$ above sea level in Nejran. Similar relationships were found with temperature and stations altitudes in the study of EINesr and Alazba (2010), which may be a significant reason for rising $\mathrm{ET}_{\mathrm{o}}$ values.

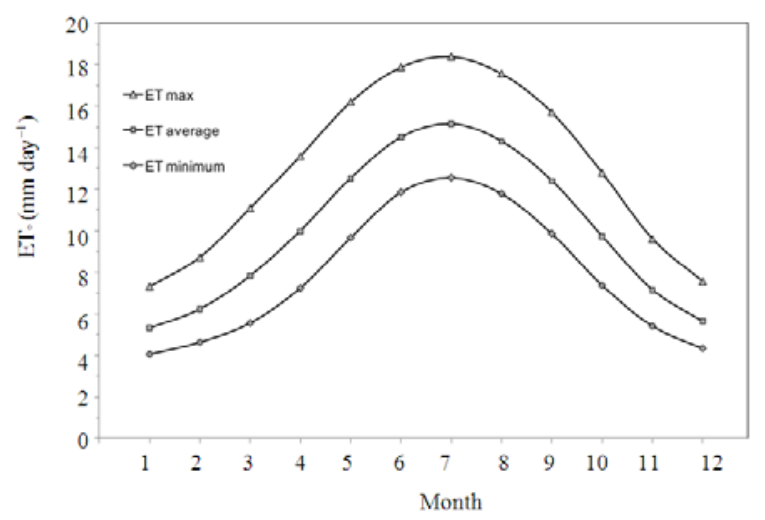

Fig. 2: The monthly average $\mathrm{ET}_{\mathrm{o}}$ variations during the year in KSA

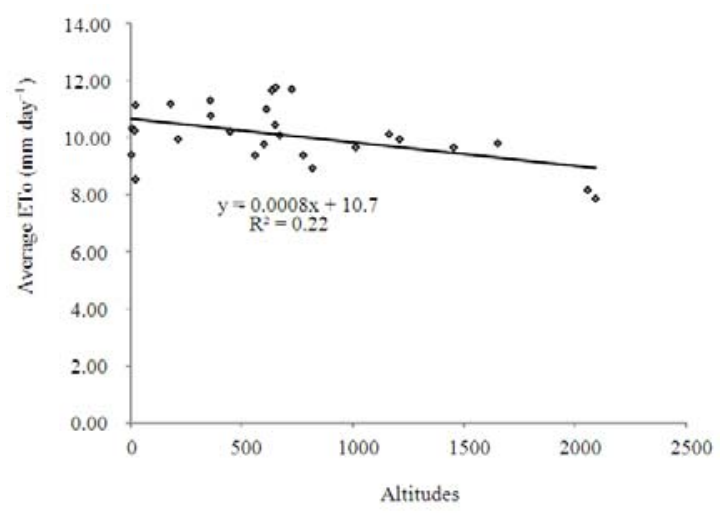

Fig. 3: Relationship between the average annual $\mathrm{ET}_{\mathrm{o}}$ $\left(\mathrm{mm} \mathrm{day}^{-1}\right)$ as related to station altitudes 


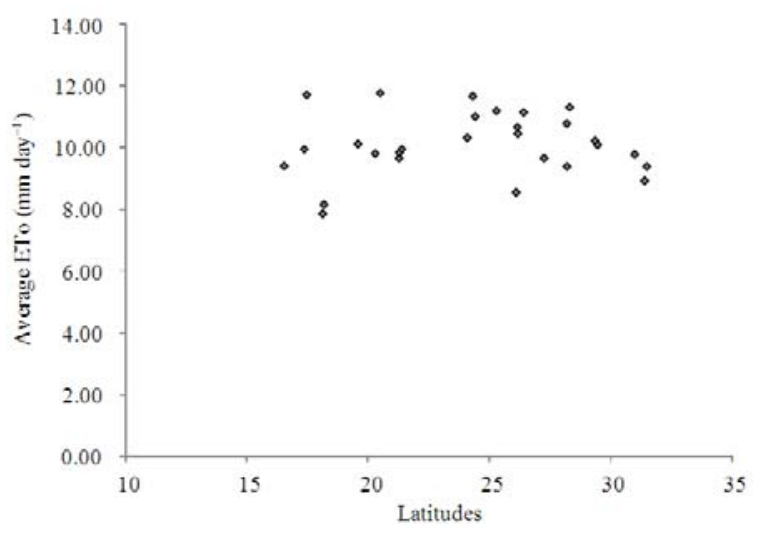

Fig. 4: Relationship between the average annual $\mathrm{ET}_{\mathrm{o}}$ $\left(\mathrm{mm} \mathrm{day}^{-1}\right)$ as related to station latitudes. Notice that no trend found to show

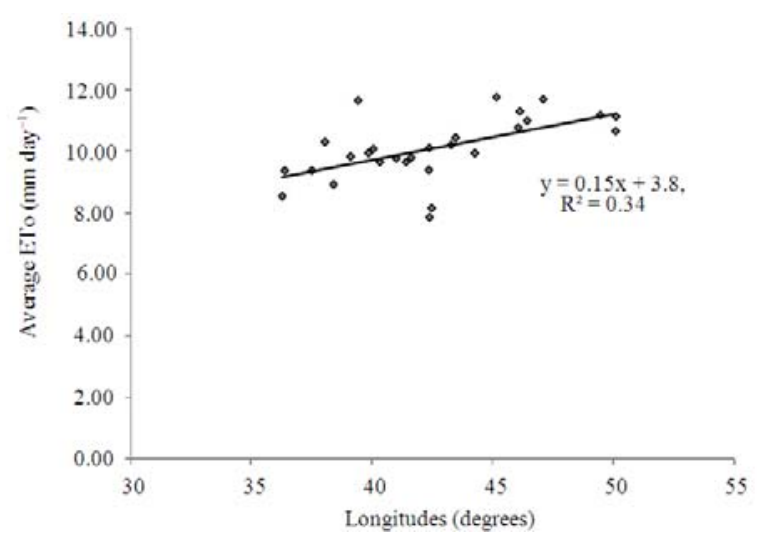

Fig. 5: Relationship between the average annual $\mathrm{ET}_{\mathrm{o}}$ $\left(\mathrm{mm} \mathrm{day}{ }^{-1}\right)$ as related to station longitudes.

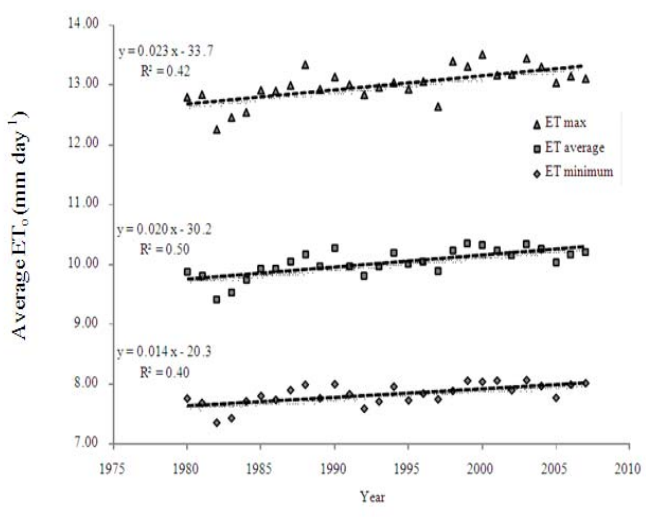

Fig. 6: Time variation of the average, maximum and minimum $\mathrm{ET}_{\mathrm{o}}$ for the study period
However, large variabilities were also observed among stations at the sea level suggesting that other factors may have compound effect on $\mathrm{ET}_{\mathrm{o}}$ in Saudi Arabia such as the geographic location (latitude and longitude). While latitudes seemed to have no effect on the variability of $\mathrm{ET}_{\mathrm{o}}$, Fig. 4, longitudes have tangible effect on it, as shown in Fig. 5. $\mathrm{ET}_{\mathrm{o}}$ increased steadily with stations longitudes as we travel toward the east. The concentration of oil industries and refineries in the eastern parts of KSA may have affected air temperature, while the nearness to the Arabian Gulf increased the relative humidity, thus leads to raising $\mathrm{ET}_{0}$ in the eastern parts of KSA relative to the other parts.

The changes in $\mathrm{ET}_{\mathrm{o}}$ with time was examined by calculating the average daily evapotranspiration $(\mathrm{mm}$ day $^{-1}$ ) over the whole study period of each station and plotting time series $\mathrm{ET}_{\mathrm{o}}$ for the study period, Fig. 6. The Fig. 6 shows clearly a positive trend of $\mathrm{ET}_{\mathrm{o}}$ with time during the study period. The $\mathrm{ET}_{\mathrm{o}}$ has increased from about 9.6 in 1980 to about $10.4 \mathrm{~mm} \mathrm{day}^{-1}$ in 2008 at a rate of $0.02 \mathrm{~mm} \mathrm{day}^{-1}$. Regression analysis between $\mathrm{ET}_{\mathrm{o}}$ and time has confirmed the positive trend and showed that the slope of the line was 0.020 with $\mathrm{R}^{2}=0.50$. However, this relationship was not statistically significant at $95 \%$ probability level. Longer period of data analysis is needed to confirm this result. Nevertheless, the present analysis indicates clearly that climate variability is indeed affecting the country and the evapotranspiration demand is increasing with time.

Due to some restrictions in Man-Kendall and Sen's methods, two stations out of the 29 stations were omitted from calculations due to the small number of years they had (less than 10 years); those were stations \#3 (Guraiat) and \# 13 (Dammam). Mann-Kendall and Sen Slope statistics were performed on the rest 27 stations on monthly basis to confirm trends direction and test its significance. Two parameters were calculated namely Kendall $\tau$ and Sen Slope Q and their confidence limits at 95 and $99 \%$ probability level as described in Materials and Methods. A group of selected results is shown in Fig. 7 where the parameters of Mann-Kendall and Sen Slope and their significant tests are presented. The Fig. 7 represents ET trends in January for four stations, Tabuk, Sharurrah Yenbo and Hail, showing possible combinations of Mann-Kendall (MK) and Sen Statistic, in addition to their significance under increasing or decreasing $\mathrm{ET}_{\mathrm{o}}$ conditions. That is, Fig. 7a showing a downtrend with MK and Sen significant at 95 and $99 \%$. Figure $7 \mathrm{~b}$ showing a downtrend with only MK is significant at $95 \%$. Figure $7 \mathrm{c}$ showing an uptrend with all statistics was significant. Figure $7 \mathrm{~d}$ showing an uptrend with only MK is significant at $95 \%$. 

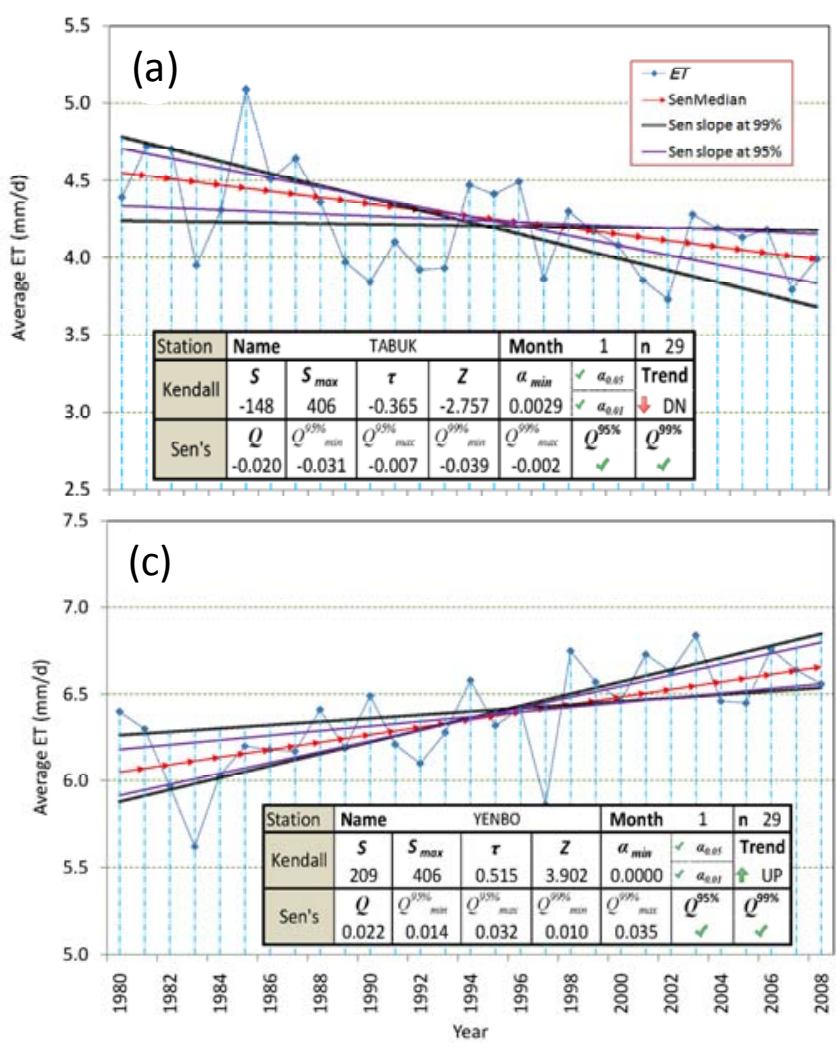
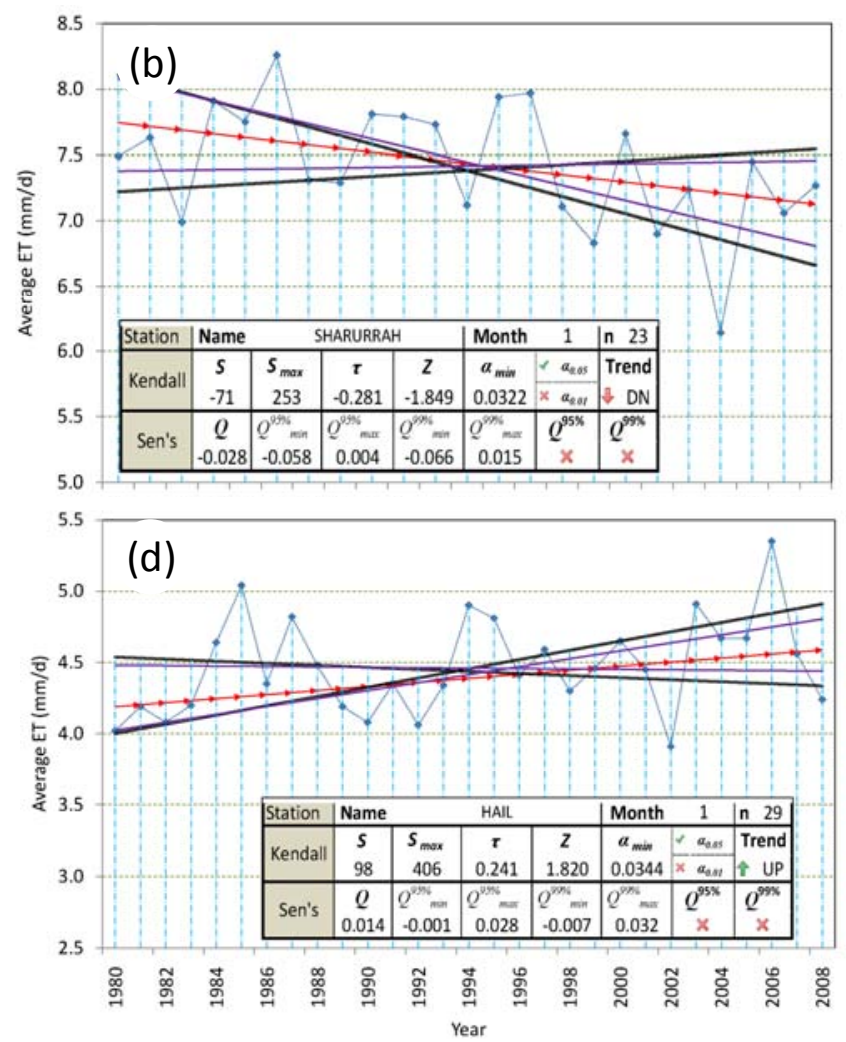

Fig. 7: Analysis of monthly average $\mathrm{ET}_{\mathrm{o}}$ trends using Mann-Kendall and Sen slope estimator and their significant tests parameters: Tabuk, A; Sharurrah, B; Yenbo, C; Hail, D

The two tests gave similar results in all of these cases but Sen Slope test were found to be more conservative. A positive sign in $\tau$ or $\mathrm{Q}$ indicates an increasing trend, Fig. $7 \mathrm{C}$ and $\mathrm{D}$ while a negative value indicates a decreasing trend, Fig. $7 \mathrm{~A}$ and $\mathrm{B}$. The significance of $\tau$ was tested by comparing the calculated $\alpha_{\min }$ with $\alpha=0.05$ or 0.01 for 95 and $99 \%$ confidence level, respectively; $\alpha_{\min }<0.05$ or 0.01 . The corresponding significant test for Q was carried out by calculating its confidence intervals at 95 and $99 \%$ indicated by $\left(\mathrm{Q}_{\min }^{95 \%}, \mathrm{Q}_{\max }^{95 \%}\right)$ and $\left(\mathrm{Q}_{\min }^{99 \%}, \mathrm{Q}_{\max }^{99 \%}\right)$, respectively. If the two limits have similar sign, then the calculated Sen Slope Q value is confirmed not to be zero and therefore the slope is significantly different from zero, indicating a positive or negative trend for $+\mathrm{Q}$ or $-\mathrm{Q}$, respectively.

Figure 7A-D represents four possible cases of $Q$ and $\tau$ and their significance. In Tabuk and Sharurrah, both $\mathrm{Q}(-0.020,-0.028)$ and $\tau(-0.365,-0.281)$, respectively, were negative indicating a decreasing trend for $\mathrm{ET}_{\mathrm{o}}$. However, this decrease is significant for Tabuk and not significant for Sharurrah at 99\% probability level as confirmed by both statistical methods. In the case of Tabuk, the value of calculated $\alpha_{\min }=0.0029$ is less than 0.01 indicating a significant trend according to Mann-Kendall test; for Sen slope test the $99 \%$ minimum and maximum values of the confidence interval are both negative indicating that the slope $\mathrm{Q}$ is not zero and therefore a negative trend is confirmed. However, for Sharurrah stations $\alpha_{\min }=0.03$ is less than 0.05 but larger than 0.01 indicating that the positive trend is significant at $95 \%$ but not at $99 \%$ level according to Mann-kendall test. A slightly different result was found in Sharurrah with Sen slope test. The upper limits for the Q confidence interval at $95 \%$ and $99 \%$ were both larger than zero $\left(\mathrm{Q}_{\max }^{95 \%}=0.004, \quad \mathrm{Q}_{\max }^{99 \%}=0.015\right)$ indicating that the median slope of the $\mathrm{ET}_{\mathrm{o}}$ series, $\mathrm{Q}$, can actually be zero and therefore the negative trend is not significant at both levels. This results show that Sen Slope test can be more conservative than Mann-Kendall test. 
Am. J. Environ. Sci., 6 (6): 535-547, 2010

Table 2: Monthly trends in the average $\mathrm{ET}_{\mathrm{o}}$ as estimated from Sen's slope statistics (Q) for various meteorological Station. Numbers in parenthesis indicate number of significant values $\left({ }^{*}\right.$ : values significant at $0.05,{ }^{\bullet}$ : values significant at 0.01 )

\begin{tabular}{|c|c|c|c|c|c|c|c|c|c|c|c|c|c|c|}
\hline \multirow[b]{2}{*}{ Station } & \multicolumn{11}{|c|}{ Month Number } & \multirow[b]{2}{*}{12} & \multicolumn{2}{|c|}{ Number of months } \\
\hline & 1 & 2 & 3 & 4 & 5 & 6 & 7 & 8 & 9 & 10 & 11 & & Increasing & Decreasing \\
\hline Turaif & 0.009 & 0.017 & $0.038^{\bullet}$ & 0.025 & $0.059^{\circ}$ & $0.064^{\bullet}$ & $0.055^{\circ}$ & $0.079^{\circ}$ & $0.034^{*}$ & $0.036^{*}$ & 0.015 & 0.012 & $12(7)$ & $0(0)$ \\
\hline ARAR & 0.010 & 0.010 & $0.046^{\bullet}$ & $0.044^{*}$ & $0.063^{\circ}$ & $0.099^{\bullet}$ & $0.089^{*}$ & $0.085^{\circ}$ & $0.058^{\bullet}$ & 0.062 & 0.024 & 0.015 & $2(8)$ & (0) \\
\hline $\mathrm{Al}$ jouf & 0.009 & 0.016 & $0.025^{*}$ & 0.032 & $0.040^{\bullet}$ & $0.044^{\bullet}$ & $0.042^{*}$ & $0.060^{\circ}$ & 0.021 & $0.033^{*}$ & 0.029 & 0.008 & $12(6)$ & $(0)$ \\
\hline Rafha & -0.018 & -0.018 & 0.012 & 0.006 & -0.007 & 0.025 & 0.019 & -0.002 & -0.018 & 0.009 & -0.002 & -0.016 & $5(0)$ & $7(0)$ \\
\hline Qaisumah & -0.013 & 0.008 & 0.006 & 0.007 & -0.012 & $-0.059^{\bullet}$ & $-0.090^{\bullet}$ & $-0.065^{\circ}$ & $-0.046^{*}$ & -0.006 & -0.009 & -0.021 & $3(0)$ & $9(4)$ \\
\hline Tabuk & $-0.020^{\bullet}$ & -0.007 & -0.007 & -0.012 & -0.020 & -0.005 & -0.018 & -0.011 & $-0.025^{*}$ & -0.002 & -0.010 & $-0.021^{*}$ & $1(0)$ & 11(3) \\
\hline Hafr al-batin & 0.015 & $0.065^{*}$ & ${ }^{*} 0.132^{\circ}$ & $0.139^{\bullet}$ & $0.119^{*}$ & 0.094 & -0.005 & 0.068 & 0.023 & 0.039 & 0.014 & -0.038 & $10(4)$ & $2(0)$ \\
\hline Hai & 0.014 & $0.032^{\bullet}$ & • $0.039^{\bullet}$ & $0.049^{\circ}$ & $0.049^{\bullet}$ & $0.072^{\bullet}$ & $0.060^{\bullet}$ & $0.074^{\bullet}$ & $0.047^{*}$ & $0.035^{*}$ & 0.020 & 0.017 & $12(9)$ & $0(0)$ \\
\hline Wejh & $-0.016^{*}$ & -0.010 & -0.017 & -0.018 & -0.016 & -0.027 & 0.005 & -0.013 & -0.006 & -0.008 & 0.004 & -0.001 & $2(0)$ & $10(1)$ \\
\hline Gassim & -0.008 & $0.025^{*}$ & ${ }^{*} 0.037$ & $0.062^{*}$ & 0.038 & $0.048^{\bullet}$ & 0.025 & 0.036 & $0.039^{*}$ & 0.012 & 0.015 & 0.010 & 11(4) & $1(0)$ \\
\hline Dhahran & 0.011 & $0.030^{\bullet}$ & $\bullet-0.063^{\bullet}$ & $0.045^{*}$ & $0.062^{*}$ & 0.032 & $0.047^{*}$ & -0.026 & $0.030^{*}$ & 0.020 & $0.026^{*}$ & 0.009 & $11(7)$ & $1(0)$ \\
\hline Ahsa & -0.018 & -0.012 & 0.010 & 0.014 & $-0.077^{*}$ & $-0.070^{*}$ & $-0.101^{\bullet}$ & $-0.110^{*}$ & $-0.053^{*}$ & $-0.058^{\bullet}$ & $-0.033^{*}$ & -0.014 & $2(0)$ & $10(7)$ \\
\hline Madina & -0.011 & 0.016 & 0.005 & 0.024 & -0.010 & 0.013 & 0.006 & 0.020 & 0.025 & -0.003 & 0.012 & 0.006 & $8(0)$ & $4(0)$ \\
\hline Riyadh (new) & -0.008 & 0005 & -0.002 & 0.050 & 0.020 & 0.021 & -0.023 & -0.016 & 0.030 & 0.026 & 0.002 & 0.002 & $9(0)$ & $3(0)$ \\
\hline old) & 0 & 0. & $\bullet 0.033$ & 0.047 & $0.051^{\bullet}$ & 0.009 & -0.003 & $0 .($ & 0. & 0.013 & 0.005 & 10 & $11(2)$ & $1(0)$ \\
\hline Yenbo & $0.022^{\bullet}$ & $0.040^{\bullet}$ & • $0.049^{\bullet}$ & $0.037^{\bullet}$ & $0.058^{\bullet}$ & $0.070^{\bullet}$ & $0.053^{*}$ & $0.072^{\bullet}$ & $0.071^{\bullet}$ & $0.050^{\bullet}$ & $0.036^{\bullet}$ & $0.032^{\bullet}$ & $12(12)$ & $0(0)$ \\
\hline Jeddah & -0.001 & -0.002 & 0.002 & 0.001 & $0.034^{\bullet}$ & $0.023^{*}$ & $0.023^{\bullet}$ & 0.016 & 0.008 & 0.013 & 0.009 & -0.006 & $9(3)$ & $3(0)$ \\
\hline Makkah & -0.002 & 0.005 & 0.000 & -0.005 & -0.002 & -0.006 & -0.019 & -0.024 & -0.023 & -0.024 & -0.018 & -0.007 & $1(0)$ & $10(1)$ \\
\hline Taif & 0.010 & $0.040^{\circ}$ & - $0.028^{*}$ & $0.026^{*}$ & $0.046^{\circ}$ & $0.063^{\circ}$ & $0.055^{*}$ & $0.033^{\circ}$ & $0.030^{\circ}$ & $0.022^{*}$ & 0.014 & 0.008 & $12(9)$ & $0(0)$ \\
\hline Baha & $-0.027^{*}$ & -0.012 & -0.015 & 0.017 & 0.013 & 0.020 & 0.000 & 0.008 & -0.015 & -0.013 & -0.031 & -0.021 & $5(0)$ & $7(1)$ \\
\hline W-Dawasir & 0.000 & 0.033 & $0.052^{*}$ & 0.009 & 0.002 & 0.006 & -0.026 & $0.033^{*}$ & 0.014 & 0.013 & $0.029^{*}$ & 0.012 & $10(3)$ & $1(0)$ \\
\hline Bisha & -0.001 & 0018 & 0.017 & 0.024 & 0.023 & $0.037^{*}$ & 0.020 & $0.037^{\bullet}$ & $0.036^{*}$ & 0.025 & 0.015 & 0.007 & $11(3)$ & $1(0)$ \\
\hline Abha & 0.000 & $0.032^{\bullet}$ & • $0.036^{\bullet}$ & $0037^{\circ}$ & 0.024 & 0.005 & 0.000 & 0.016 & $0.021^{*}$ & $0.025^{*}$ & 0.008 & 0.006 & $10(5)$ & $0(0)$ \\
\hline Khamis Mushai & it 0.009 & $0.028^{\circ}$ & $\bullet$ & $0.031^{*}$ & $0.039^{\bullet}$ & $0.034^{*}$ & 0.013 & $0.028^{\bullet}$ & $0.035^{\circ}$ & $0.030^{\circ}$ & 0.015 & 0.012 & $12(8)$ & $0(0)$ \\
\hline Nejran & -0.011 & -0.004 & -0.009 & -0.002 & -0.24 & $-0.044^{*}$ & $-0.042^{*}$ & -0.032 & -0.017 & -0.016 & -0.017 & -0.007 & $0(0)$ & $12(2)$ \\
\hline Sharurrah & -0.028 & -0.044 & $-0.052^{*}$ & 0.008 & -0.062 & -0.058 & $-0.091^{*}$ & -0.078 & $-0.072^{*}$ & $-0.081^{\bullet}$ & -0.026 & -0.023 & $1(0)$ & $11(4)$ \\
\hline Gizan & 0.000 & 0.000 & 0.001 & 0.000 & -0.002 & 0.003 & 0.007 & -0.006 & -0.003 & $-0.012^{*}$ & -0.002 & 0.000 & $5(0)$ & (1) \\
\hline & & 19(9) & $20(11)$ & $23(9)$ & & $20(10)$ & 15( & 18( & & & & & & \\
\hline Decreasin & 1s. $14(3)$ & $8(0)$ & $6(1)$ & $4(0)$ & $10(1)$ & $7(3)$ & 11(4) & $9(2)$ & $10(4)$ & $10(4)$ & $9(1)$ & 11(1) & & \\
\hline
\end{tabular}

Both Yenbo and Hail have increasing $\mathrm{ET}_{\mathrm{o}}$ trends, as shown in Fig. 7C and D, because $\tau$ and $\mathrm{Q}$ values were both positive $(\mathrm{Q}=0.022, \tau=0.515$ for Yenbo; while $\mathrm{Q}=0.01$ and $\tau=0.24$ for Hail). Both tests showed that $\mathrm{ET}_{\mathrm{o}}$ in Yenbo is increasing significantly at 95\% as well as at $99 \%$ level since $\tau$ and Q were positive and $\alpha_{\min }=0.000<0.05$ and $\mathrm{Q}_{\min }^{95 \%}>0.0$. However, in Hail this uptrend was significant according to Mann-Kendall $\left(\alpha_{\min }=0.000<0.05\right)$ at $95 \%$ level but not significant according to Sen Slope since $Q_{\min }^{95 \%}=-0.001$ indicating the possibility of the slope being zero. These results indicated the validity of these two statistical methods to detect trends in a time series data.

The previous analyses shown in Fig. 7 were carried out for the 27 stations out of 29 under study. ManKendall and Sen's methods' can deal with data series with 10 or more data points. However, Gurrayat and Dammam have less than 10 years of data and they were excluded from trend analysis. Average $\mathrm{ET}_{\mathrm{o}}$ time series were analyzed for each month and the resultant Sen slope $\mathrm{Q}$ and Kendall $\tau$ are shown in Table 2 and 3, respectively followed by up or down arrows to indicate their significance. Up-arrows in light or dark black indicate significance up trend while similar light and dark black down arrows indicate a significant down trends at 95 and 99\% probability level, respectively. Numbers without arrows are not statistically significant. The total number of stations with a decreasing or increasing trend in each month were calculated and shown at the bottom of the table. Whereas the number of months at which stations showed a decreasing or increasing trends were shown for each station at the right side of the table. Numbers between brackets indicates the number of months or stations with the corresponding significant trend. The tests were carried out for maximum, minimum and average monthly $\mathrm{ET}_{\mathrm{o}}$ but only the average $\mathrm{ET}_{\mathrm{o}}$ is shown in the Tables, because extreme $\mathrm{ET}_{\mathrm{o}}$ showed similar behavior to that of average $\mathrm{ET}_{\mathrm{o}}$.

Fourteen stations have a positive $Q$ and $\tau$, for at least 10 months in a year therefore an uptrend in ETo namely; Turaif, Arar, Al jouf, Hafr Al-Baten, Hail, Gassim, Dhahran, Riyadh (old), Yenbo, Taif, Wdawaser, Bisha, Abha and khamis Mushait. Another six stations showed a negative or zero $Q$ during the whole year, therefore a downtrend in $\mathrm{ET}_{\mathrm{o}}$ including; Tabuk, Wejh, Makkah, Nejran, Sharurrah and Gizan. 
Am. J. Environ. Sci., 6 (6): 535-547, 2010

Table 3: Monthly trends in the Average ETo as estimated from Mann-kendall statistic $(\tau)$ for various meteorological Station. Numbers in parenthesis indicate number of significant values. $\left(^{*}\right.$ : values significant at $0.05,{ }^{\bullet}$ : values significant at 0.01$)$

\begin{tabular}{|c|c|c|c|c|c|c|c|c|c|c|c|c|c|c|}
\hline \multirow[b]{2}{*}{ Station } & \multicolumn{11}{|c|}{ Month number } & \multirow[b]{2}{*}{12} & \multicolumn{2}{|c|}{ Number of months } \\
\hline & 1 & 2 & 3 & 4 & 5 & 6 & 7 & 8 & 9 & 10 & 11 & & Increasing & Decreasing \\
\hline & 0.16 & $0.23^{*}$ & $0.39^{\bullet}$ & $0.24^{*}$ & 0.38 & $0.46^{\circ}$ & $0.37^{\circ}$ & $0.41^{\circ}$ & $0.28^{*}$ & $0.29^{*}$ & 0.13 & 0.14 & $12(9)$ & $0(0)$ \\
\hline Aarar & 0.19 & 0.14 & $0.36^{\bullet}$ & $0.32^{\bullet}$ & $0.44^{\bullet}$ & $0.54^{\bullet}$ & $0.33^{\bullet}$ & $0.40^{\bullet}$ & $0.40^{\bullet}$ & $0.43^{\circ}$ & $0.24^{*}$ & 0.22 & $12(9)$ & $0(0)$ \\
\hline $\mathrm{Al}$ jouf & 0.13 & 0.20 & $0.33^{\bullet}$ & $0.22^{*}$ & $0.37^{\bullet}$ & $0.50^{\bullet}$ & $0.33^{\bullet}$ & $0.48^{\bullet}$ & 0.21 & $0.30^{*}$ & $0.26^{*}$ & 0.12 & $12(8)$ & $0(0)$ \\
\hline Rafha & $-0.24^{*}$ & -0.17 & 0.09 & 0.04 & -0.07 & 0.17 & 0.05 & -0.01 & -0.14 & 0.08 & -0.01 & -0.15 & $5(0)$ & $7(0)$ \\
\hline Qaisumah & -0.16 & 0.08 & 0.03 & 0.04 & -0.10 & $-0.39^{\bullet}$ & $-0.46^{\bullet}$ & $-0.47^{\bullet}$ & $-0.34^{\bullet}$ & -0.06 & -0.06 & -0.17 & $3(0)$ & $9(4)$ \\
\hline Tabuk & $-0.36^{\bullet}$ & -0.08 & -0.14 & -0.20 & -0.06 & -0.20 & -0.14 & 0.01 & $-0.28^{*}$ & -0.02 & -0.16 & $-0.33^{\bullet}$ & $1(0)$ & $11(3)$ \\
\hline Hafr al-batin & 0.09 & $0.43^{\circ}$ & $0.57^{\bullet}$ & $0.49^{\bullet}$ & $0.43^{\bullet}$ & $0.32^{*}$ & -0.02 & $0.30^{*}$ & 0.12 & 0.20 & 0.07 & -0.13 & $10(6)$ & $2(0)$ \\
\hline Hail & $0.24^{*}$ & $0.43^{\circ}$ & $0.39^{\bullet}$ & $0.40^{\circ}$ & $0.47^{\bullet}$ & $0.50^{\bullet}$ & $0.44^{\bullet}$ & $0.57^{\bullet}$ & $0.33^{\bullet}$ & $0.28^{*}$ & 0.15 & 0.22 & $12(10)$ & $0(0)$ \\
\hline Wejh & -0.31 & -0.16 & $-0.23^{*}$ & -0.20 & -0.18 & -0.16 & 0.12 & -0.10 & -0.03 & -0.12 & 0.07 & -0.01 & $2(0)$ & $10(2)$ \\
\hline Gassim & -0.10 & $0.29^{*}$ & 0.25 & $0.32^{\bullet}$ & $0.23^{*}$ & 0.39 & 0.16 & $0.24^{*}$ & $0.28^{*}$ & 0.13 & 0.14 & 0.10 & $11(7)$ & $1(0)$ \\
\hline Dhahran & 0.17 & $0.38^{\circ}$ & $0.47^{\bullet}$ & $0.32^{\bullet}$ & $0.32^{\bullet}$ & 0.21 & $0.27^{*}$ & -0.18 & $0.33^{\bullet}$ & 0.21 & $0.35^{\circ}$ & 0.17 & $11(7)$ & $1(0)$ \\
\hline Ahsa & -0.22 & -0.12 & 0.04 & 0.13 & $-0.35^{\bullet}$ & $-0.32^{*}$ & $-0.38^{\bullet}$ & $-0.36^{\bullet}$ & $-0.35^{\bullet}$ & $-0.44^{\bullet}$ & $-0.39^{\bullet}$ & -0.13 & $2(0)$ & $10(7)$ \\
\hline Madina & -0.17 & 0.12 & 0.10 & 0.15 & -0.06 & 0.09 & 0.06 & 0.12 & $0.24^{*}$ & -0.05 & 0.15 & 0.08 & $8(1)$ & $4(0)$ \\
\hline Riyadh (new) & -0.10 & 0.07 & -0.01 & 0.22 & 0.14 & 0.12 & -0.18 & -0.18 & 0.24 & 0.19 & 0.01 & 0.04 & $9(0)$ & $3(0)$ \\
\hline Riyadh (old) & 0.13 & $0.35^{\circ}$ & $0.25^{*}$ & $0.22^{*}$ & $0.43^{\circ}$ & 0.10 & -0.05 & 0.06 & 0.20 & 0.13 & 0.06 & 0.11 & 11(4) & $1(0)$ \\
\hline Yenbo & $0.51^{\bullet}$ & $0.41^{\circ}$ & $0.47^{\bullet}$ & $0.39^{\circ}$ & $0.41^{\bullet}$ & $0.43^{\bullet}$ & $0.33^{\bullet}$ & $0.40^{\bullet}$ & $0.48^{\bullet}$ & $0.51^{\bullet}$ & $0.38^{\bullet}$ & $0.41^{\bullet}$ & $12(12)$ & $0(0)$ \\
\hline Jeddah & -0.02 & -0.04 & 0.03 & 0.03 & $0.39^{\bullet}$ & $0.31^{*}$ & $0.39^{\circ}$ & 0.21 & 0.10 & 0.16 & 0.11 & -0.10 & $9(3)$ & $3(0)$ \\
\hline Makkah & -0.04 & 0.05 & 0.00 & -0.05 & -0.03 & -0.06 & -0.18 & $-0.28^{*}$ & $-0.26^{*}$ & $-0.41^{\bullet}$ & -0.21 & -0.11 & $2(0)$ & $10(3)$ \\
\hline Taif & 0.18 & $0.55^{\circ}$ & $0.32^{\bullet}$ & $0.31^{*}$ & $0.36^{\circ}$ & $0.41^{\bullet}$ & $0.29^{*}$ & $0.36^{\bullet}$ & $0.38^{\bullet}$ & $0.31^{*}$ & $0.23^{*}$ & 0.13 & $12(10)$ & $0(0)$ \\
\hline Baha & $-0.38^{\bullet}$ & -0.11 & -0.10 & 0.11 & 0.11 & 0.19 & 0.00 & 0.10 & -0.09 & -0.12 & -0.21 & -0.18 & $4(0)$ & $7(1)$ \\
\hline W-Dawasir & 0.02 & $0.27^{*}$ & $0.34^{*}$ & 0.06 & 0.01 & 0.04 & -0.14 & $0.35^{\circ}$ & 0.08 & 0.17 & $0.32^{*}$ & 0.10 & $11(4)$ & $1(0)$ \\
\hline Bisha & -0.03 & 0.21 & 0.14 & 0.14 & 0.18 & $0.34^{\bullet}$ & 0.15 & $0.34^{\bullet}$ & $0.29^{*}$ & 0.21 & 0.16 & 0.13 & $11(3)$ & $1(0)$ \\
\hline Abha & 0.00 & $0.46^{\circ}$ & $0.35^{\bullet}$ & $0.35^{\circ}$ & $0.25^{*}$ & & 0.00 & 0.21 & $0.28^{*}$ & $0.31^{\bullet}$ & 0.19 & 0.11 & $11(6)$ & $0(0)$ \\
\hline Khamis Mushai & it 0.13 & $0.35^{\circ}$ & $0.40^{\circ}$ & $0.33^{\bullet}$ & $0.35^{\circ}$ & $0.31^{*}$ & 0.14 & $0.42^{\bullet}$ & $0.38^{\bullet}$ & $0.36^{\circ}$ & 0.22 & 0.15 & $12(8)$ & $0(0)$ \\
\hline Nejran & -0.18 & -0.05 & -0.11 & -0.04 & -0.18 & $-0.32^{\bullet}$ & $-0.31^{*}$ & $-0.22^{*}$ & -0.15 & -0.12 & $-0.25^{*}$ & -0.09 & $0(0)$ & $12(4)$ \\
\hline Sharurrah & $-0.28^{*}$ & $-0.26^{*}$ & $-0.36^{\bullet}$ & 0.04 & $-0.25^{*}$ & $-0.27^{*}$ & $-0.36^{\bullet}$ & $-0.28^{*}$ & $-0.37^{\bullet}$ & $-0.41^{\bullet}$ & -0.16 & -0.21 & $1(0)$ & $11(9)$ \\
\hline Gizan & 0.01 & 0.01 & 0.03 & 0.01 & -0.04 & 0.04 & 0.10 & -0.10 & -0.07 & $-0.29^{*}$ & -0.03 & 0.00 & $6(0)$ & $5(1)$ \\
\hline & & $19(11) 2$ & 21(13) & (12) & $17(13) 2$ & $20(11) 1$ & & $18(11)$ & & $17(8)$ & $18(6)$ & & & \\
\hline Decreasing Stn & ls. $14(5)$ & $8(1)$ & $6(2)$ & $4(0)$ & $10(2)$ & $7(4) \quad 1$ & $12(4)$ & $9(5)$ & $10(5)$ & $10(4)$ & $9(2)$ & $11(1)$ & & \\
\hline
\end{tabular}

The other seven stations showed a mix of increasing and decreasing trends during the year and those are Rafha, Qaisumah, Ahsa, Madina, Riyadh (new), Jeddah and Baha.

However, the up or down trends or downtrends in $\mathrm{ET}_{\mathrm{o}}$ in the first mentioned group were not always significant as indicated by the upward arrows and summed in the last two columns of Table 2 and 3. Only Yenbo had a confirmed significant trend at $95 \%$ level during the entire year. Other stations showed a significant up trends in $\mathrm{ET}_{\mathrm{o}}$ for several months during the year including Hail and Taif, 10 months; Turaif and Arar, 9 months; Al jouf and Khamis Mushait, 8 months. The other stations among the uptrend group had significant uptrend in 3-7 months in a year as shown in Table 2.

The number of stations with a decreasing trend is far less than those with increasing $\mathrm{ET}_{\mathrm{o}}$. Few stations showed a decreasing trend in $\mathrm{ET}_{\mathrm{o}}$ for 9 months or higher including, Qaisumah, Tabuk, Wejh, Ahsa, Makkah, Nijran and Sharurrah. However, only Ahsa station had a significant decreasing trend for 7 months followed by Qaisumah and Sharurrah, 4 months and
Tabuk with only 3 months of declining in $\mathrm{ET}_{\mathrm{o}}$. The rest of stations, Wejh, Makkah, Nejran, Gizan, had a decreasing trend but this trend is not significant at 95\% probability level.

The numbers of stations with increasing or decreasing trend are shown in the last two rows of Table 2 and 3. At least 15 stations or higher showed an increasing trend for the entire year except in January at which 14 stations showed a decreasing trend. March, April and June showed the highest number of stations with increasing $\mathrm{ET}_{\mathrm{o}}$. However, the significant increase in $\mathrm{ET}_{\mathrm{o}}$ were confirmed for about 10 stations and for 9 months, February to October. During the months of October to January, about 10 stations showed a decreasing trend but this decrease was significant for only 4 stations in September and October, one station in November and December and 3 stations in January. Figure 8 showed clearly that the regions with decreasing trends is concentrated in winter months having high humidity, October to January and areas with significant decrease in $\mathrm{ET}_{\mathrm{o}}$ to $90 \%$ are very limited as shown by the dark dotted regions. 


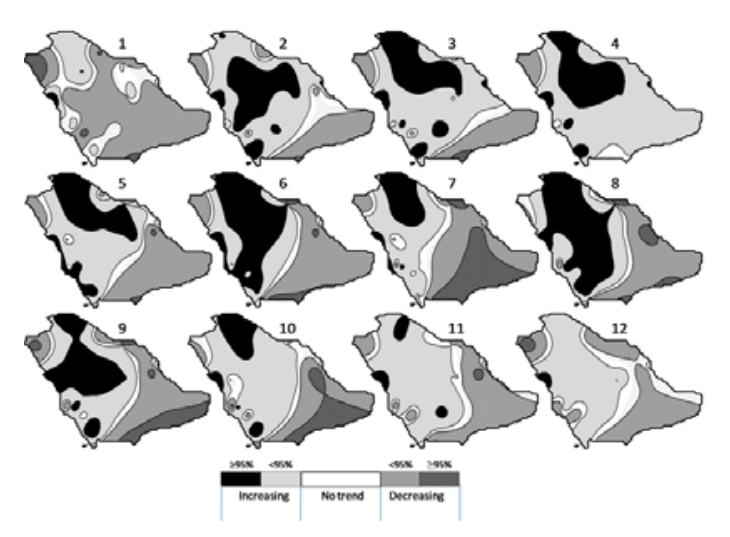

Fig. 8: Contour plots of Kendall $Z$ statistic for the average monthly $\mathrm{ET}_{\mathrm{o}}$ trend in various months during the past 29 years

Further inspection on the location of stations with increasing trends in $\mathrm{ET}_{\mathrm{o}}$ revealed that most of these stations are located in the northern part of the Arabian peninsula north to the latitude line of $22^{\circ}$. However, some other stations were located southern of this line at the southern west corner of Saudi Arabia. It seemed that stations located along the longitudinal line of $4^{\circ} 5$ showed an increasing trend. Actually the wind direction over the Arabian peninsula seemed to follow this line from south west to north in rainy seasons and from north to south west in the dry seasons.

To have an aerial graph for the regions with a decreasing or increasing trend in $\mathrm{ET}_{\mathrm{o}}$ a contour map were plotted for each months and the results are shown in Fig. 8. Darker colors indicate regions with significant increasing trends while white and dashed colors indicate regions with no or decreasing trends. Indeed, regions with increasing trends are concentrated in the northern part of Saudi Arabia and extended to the south along the $45^{\circ}$ longitudinal line. Significant and increasing regions, indicated by black and grey regions $(\mathrm{p}>95 \%)$ are prevail for most of the year except in January and July to some extent. In January most of SA areas have decreasing $\mathrm{ET}_{\mathrm{o}}$ as shown in Fig. 8 and also in Table 3 where 14 stations have a decreasing trends; although this decrease is not significant at $95 \%$ level except for 3 stations. The southeastern parts seemed to have decreasing trends most of the years, but also this trend is not significant at $95 \%$ except in July and October as indicated by the darker dotted regions.

\section{CONCLUSION}

Historical analysis of daily $\mathrm{ET}_{\mathrm{o}}$ in Saudi Arabia was carried out using Penman Monteith equation
(FAO-56) for 29 meteorological stations distributed all over Saudi Arabia for the period 1980-2008. The long time average daily $\mathrm{ET}_{\mathrm{o}}$ varied from about $5 \mathrm{~mm} / \mathrm{d}$ in Jan to $15 \mathrm{~mm} \mathrm{day}^{-1}$ in July which is one of the hottest months in the country. $\mathrm{ET}_{\mathrm{o}}$ time series analysis using Mann-Kendall and Sen slope statistics revealed that $\mathrm{ET}_{\mathrm{o}}$ has been increasing steadily during the study period. The average minimum and maximum daily $\mathrm{ET}_{\mathrm{o}}$ increased steadily and $\mathrm{ET}_{\mathrm{o}}$ average increased from about 9.6 to about $10.4 \mathrm{~mm}$ day $^{-1}$ in 2008. Trend analysis revealed that about 14 of the weather stations showed a significant increasing trend in $\mathrm{ET}_{\mathrm{o}}$ during the year for more than 7 months. Only 4 stations showed decreasing trends in three months, September, October and January. Increasing $\mathrm{ET}_{0}$ trends prevail in the northern and south-west areas along the longitudinal line of $45^{\circ}$ while decreasing trends prevail in the north western spot along the red sea and south eastern parts along the Arabian Gulf. This demonstrates that $\mathrm{ET}_{\mathrm{o}}$ fluctuation is increasing with time that can be considered a significant sign for climate variability in the Arabian peninsula. This increase in $\mathrm{ET}_{\mathrm{o}}$ seemed to be mainly affected by the global warming or the increase in temperature in the Arabian peninsula which was confirmed by several studies mentioned in this study. Analyses of longer historic data are needed to confirm these findings. Nevertheless, the findings of this research suggest the needs to consider $\mathrm{ET}_{0}$ changes in the planning for agricultural and water resources projects.

\section{REFERENCES}

Abderrahman, W.A. and T.A. Bader, A.U. Kahn and M.H. Ajward, 1991. Weather modification impact on reference evapotranspiration, soil salinity and desertification in arid regions: A case study. J. Arid Environ., 20: 277-286.

Abderrahman, W.A., 2001. Water demand management in Saudi Arabia. The International Development Research Center Science of Himanity.

Abderrahman, W.A. and I.M. Al-Harazin, 2003. The impacts of global climatic change on reference crop evapotranspiration, irrigation water demands, soil salinity and desertification in Arabian Peninsula. Proceeding of the International Conference of "Desertification in the Third Millennium, Feb. 12-15, Organized by Zayed International Prize for the Environment, Dubai, pp: 67-73.

Abdullah, M.A. and M.A. Al-Mazoui 1998. Climatological study of the southwestern region of Saudi Arabia. I. Rainfall analysis. Clim. Res., 9: 213-223. 
Abramowitz, M. and I.A. Stegun, 1965. Handbook of Mathematical Functions: With Formulas, Graphs and Mathematical Tables. 1st Edn., Dover Publications, UK., ISBN-10: 0486612724, pp: 1046.

Al-Ansari, N., E. Salameh and H. Al-Omari, 1999. Analysis of rainfall in the badia region, Jordan. Research Paper No. 1, Al-al-Bayt University, Jordan.

Allen, R.G., I.A. Walter, R.L. Elliott, T.A. Howell and D. Itenfisu et al., 2005. The ASCE standardized reference evapotranspiration equation. 1st Edn., American Society of Civil Engineers Reston, America, ISBN-10: 078440805X, pp: 216.

Allen, R.G., 1998. Crop evapotranspiration: Guidelines for Computing Crop Water Requirements. 1st Edn., Food and Agriculture Organization of the United Nations, USA., ISBN-10: 9251042195, pp: 300.

Aquastat, 2008. FAO's Information System on Water and Agriculture. Climate information tool.

Bandyopadhyay, A., A. Bhadra, N.S. Raghuwanshi and R. Singh, 2009. Temporal trends in estimates of reference evapotranspiration over India. J. Hydrologic Eng., 14: 508-515. DOI: 10.1061/(ASCE)HE.1943-5584.0000006

Burman, R.D., M.E. Jensen and R.G. Allen, 1987. Thermodynamic Factors in Evapotranspiration. Proceeding of the Conference on Irrigation Systems for the 21st Century, Portland, Oregon (USA), Jul. 28-30, ASCE, New York, USA., pp: 140-148.

Cohen, S. and G. Stanhill, 1996. Contemporary climate change in Jordan Valley. J. Applied Meteorol., 35: 1051-1058. $\quad$ DOI: $\quad 10.1175 / 1520-$ 0450(1996)035<1051:CCCITJ $>2.0 . C O ; 2$

Dinpashoh, Y., 2006. Study of reference crop evapotranspiration in I.R. of Iran. Agric. Water Manage., $\quad$ 84: 123-129. DOI: 10.1016/J.AGWAT.2006.02.011

Doorenbos, J. and W.O. Pruitt, 1975. Guidelines for Predicting Crop Water Requirements. 1st Edn., Food and Agriculture Organization of the United Nations, Rome, ISBN-10: 9251002797, pp: 144.

ElNesr, M., and A. Alazba, 2010. Spatio-temporal Variability of Evapotranspiration over the Kingdom of Saudi Arabia. Accept. Publi. Applied Eng. Agric., 26: 833-842.

ElNesr, M.N., M. Abu-Zreig and A.A. Alazba, 2010. Temperature trends and distribution in the Arabian Peninsula. Am. J. Env. Sci., 6: 191-203. DOI: 10.3844/ajessp.2010.191.203
Rosemarie, F., 2007. Increasing Evapotranspiration Trends over the Mississippi River Basin. MSc. Thesis. Cornell University.

Fu, G., C.P. Stephen and J. Yu, 2009. A critical overview of pan evaporation trends over the last 50 years. Climatic Change, 97: 193-214. DOI: 10.1007/s10584-009-9579-1

Gao, G., D. Chen, C.Y. Xu and E. Simelton, 2007. Trend of estimated actual evapotranspiration over china during 1960-2002. J. Geophysical Res., 112: 11120-11128. DOI: 10.1029/2006JD008010

Garbrecht, J., M. Van Liew and G.O. Brown, 2004. Trends in precipitation, streamflow and evapotranspiration in the great plains of the united states. J. Hydrologic Eng., 9: 360-367. DOI: 10.1061/(ASCE)1084-0699(2004)9:5(360)

Hakan, A., 2010. Trend analysis of hydrometeorological parameters in climate regions of Turkey. Conference on Water Observation and Information System for Decision Support, May, 25-29, BALWOIS, Republic of Macedonia, pp: 111.

Hegerl, G.C., F.W. Zwiers, P. Braconnot, N.P. Gillett and Y. Luo et al., 2007. Understanding and Attributing Climate Change. In: Climate Change 2007: The Physical Science Basis, Solomon, S., (Ed.). Intergovernmental Panel on Climate Change, New York, pp: 663-746.

Hobbins, M.T., J.A. Ramırez and T.C. Brown, 2004. Trends in pan evaporation and actual evapotranspiration across the conterminous U.S.: Paradoxical or complementary? Geophysical Res. Lett., $\quad 31$ : 13503-13507. DOI: 10.1029/2004GL019846

Kendall, M.G. and J.D. Gibbons, 1990. Rank Correlation Methods. 5th Edn., E. Arnold,, New York, pp: 260.

Liu, B., M. Xu, M. Henderson and W. Gong, 2004. A spatial analysis of pan evaporation trends in china, 1955-2000. J. Geophysical Res., 109: 1510215110. DOI: $10.1029 / 2004 J D 004511$

Milly, P.C.D. and K.A. Dunne, 2001. Trends in evaporation and surface cooling in the Mississippi River basin. Geophys. Res. Lett., 28: 1219-1222. DOI:10.1029/2000GL012321

Momra, 2007. Ministry of Municipal and Rural Affairs. Saudi Districts.

Murray, F.W., 1967. On the computation of saturation vapor pressure. J. Appl. Meteor., 6: 203-204. DOI: $10.1175 / 1520$ 0450(1967)006<0203:OTCOSV >2.0.CO;2 
Myneni, R.B., C.D. Keeling, C.J. Tucker, G. Asrar and R.R. Nemani, 1997. Increased plant growth in the northern high latitudes from 1981-1991. Nature, 386: 698-702. DOI: 10.1038/386698a0

NIMA, 2003. National Imagery and Mapping Agency. The United States Government.

Roderick, M.L. and G.D. Farquhar, 2004. Changes in Australian pan evaporation from 1970-2002. Intl. J. Climatol., 24: 1077-1090. DOI: 10.1002/joc.1061

Saghravani, S.R., Mustapha S., Ibrahim S. and Randjbaran, E., 2009. Comparison of daily and monthly results of three evapotranspiration models in tropical zone: A case study. Am. J. Environ. Sci., 5: 698-705. DOI: 10.3844/ajessp.2009.698.705

Schwartz, P. and D. Randall, 2003. An abrupt climate change scenario and its implications for United States national security. 1st Edn., Diane Publishing Co., USA., pp: 22.

Sen, P.K., 1968. Estimates of the regression coefficient based on Kendall's TAU. J. Am. Statistical Assoc., 63: 1379-1389.

Shenbin, C., L. Yunfeng and A. Thomas, 2006. Climatic change on the Tibetan plateau: Potential evapotranspiration trends from 1961-2000. Climatic Change, 76: 291-319. DOI: 10.1007/s10584-006-9080-z

Smadi, M.M., 2006. Observed abrupt changes in minimum and maximum temperatures in Jordan in the 20th Century. Am. J. Environ. Sci., 2: 114-120. DOI:10.3844/ajessp.2006.114.120
Smadi, M.M. and A. Zghoul, 2006. A sudden change in rainfall characteristics in amman, Jordan during the mid 1950s. Am. J. Environ. Sci., 2: 84-91. DOI:10.3844/ajessp.2006.84.91

Song, Z.W., H.L. Zhang, R.L. Snyder, F.E. Anderson and F. Chen, 2010. Distribution and trends in reference evapotranspiration in the north china plain. J. Irrig. Drain. Eng., 136: 240-247.

Szilagyi, J., 2001. Modeled areal evaporation trends over the conterminous united states. J. Irrig. Drain. Eng., 127: 196-200. DOI:10.1061/(ASCE)07339437(2001)127:4(196)

Tebakari, T., J. Yoshitani and C. Suvanpimol, 2005. Time-space trend analysis in pan evaporation over kingdom of Thailand. J. Hydr. Eng., 10: 205-215.

Tetens, O., 1930. Uber einige meteorologische begriffe. Quoted from FAO, 1990. Z. Geophys. 6: 297-309.

Thomas, A., 2000. Spatial and temporal characteristics of potential evapotranspiration trends over China. Intl. J. Clim., 20: 381-396. DOI: 10.1002/(SICI)1097-0088(20000330)

Wynbrandt, J. and F.A. Gerges, 2004. A Brief History of Saudi Arabia. 1st Edn., Facts on File, Inc., Saudi Arabia, ISBN: 10: 0816052034, pp: 334. 